https://doi.org/10.30843/nzpp.2019.72.326

\title{
Current and planned research for managing the fruit fly threat to New Zealand
}

\author{
David A.J. Teulon ${ }^{1,4,}{ }^{*}$, John M. Kean ${ }^{2,4}$ and Karen F. Armstrong ${ }^{3,4}$ \\ ${ }^{1}$ The New Zealand Institute for Plant and Food Research Ltd, Private Bag 4704, Christchurch 8140, \\ New Zealand \\ ${ }^{2}$ AgResearch, Ruakura Science Centre, Private Bag 3123, Hamilton 3240, New Zealand \\ ${ }^{3}$ Bio-Protection Research Centre, PO Box 85084, Lincoln University, Lincoln 7647, New Zealand \\ ${ }^{4}$ Better Border Biosecurity (B3) (www.b3nz.org) \\ *Corresponding author: David.Teulon@plantandfood.co.nz
}

Fruit flies (Family Tephritidae), in particular the Queensland fruit fly (Bactrocera tryoni; QFF), are one of the biggest biosecurity risks for New Zealand horticulture. New Zealand has one of the best science-based biosecurity systems in the world, based on years of experience and sound research. The introduction of fruit flies to New Zealand is now well managed in commercial fruit imports, but the risk is rising from growing trade and travel and, in the case of QFF, climatic adaptation and spread to more southern localities. Smarter solutions are continually needed to manage this increasing risk, and to deal with such pests when they arrive. We present a brief summary of current and anticipated research aimed at reducing the likelihood of entry into New Zealand and/or minimising the impact for the fruit fly species of greatest threat to New Zealand. Research spans risk assessment, pathway risk management, diagnostics, surveillance and eradication.

https://doi.org/10.30843/nzpp.2019.72.322

\section{Ustilago maydis yeast stage found on imported sweet corn}

Merje Toome-Heller* and Brett J.R. Alexander

Plant Health and Environment Laboratory, Ministry for Primary Industries, P.O. Box 2095, Auckland 1140, New Zealand

*Corresponding author: merje.toome@mpi.govt.nz

During the inspection of imported sweet corn (Zea mays), a specimen with dry rot symptoms was detected by Ministry for Primary Industries quarantine officers. A sample was sent to the MPI Plant Health and Environment Laboratory for diagnostics, and initial examination found a layer of yeast cells on the surface of the symptomatic tissue. The fungus was cultured and identified based on DNA sequences as Ustilago maydis. While the corn-smut pathogen U. maydis is well known to cause tumour like galls on corn kernels, it is a less recognised fact that this fungus can also grow as a yeast. To determine if the yeast stage could have been associated with the dry-rot symptoms observed on the specimen, healthy material was inoculated with the isolated $U$. maydis strain. No symptoms developed on inoculated material, indicating that the yeast cells were likely multiplying on the surface of the cut corn ear as saprobes. To our knowledge, this is the first report of $U$. maydis yeast stage on corn ears and indicates a previously unconsidered pathway for the organism. For the yeast stage to cause disease, mating with a compatible mating type on the surface of a living host plant would be required. 